\title{
Effects of Price Attitude toward Apparel Products on Shopping Values and Consumption Behavior
}

\author{
Park Eunhee ${ }^{\star} \cdot$ Lee Sangjoo \\ Lecturer, Dept. of Clothing \& Textiles, Kyungbook National University ${ }^{\star}$ \\ Lecturer, Dept. of Business Administration, Yeungnam University
}

\begin{abstract}
The purpose of this study was to examine the effect of price-attitude toward apparel products on shopping values and consumption behavior. The study was carried out in Deagu and Kyungbook area. Applying the convenience sampling, total 326 questionnaire were collected from university students who were randomly selected as participants. This study used frequency, factor analysis, reliability analysis, regression analysis, and t-test for data analysis. The finding are as follows. Price-attitude toward apparel products was categorized into information leading, price dignity, price discount, list price orientation, quality value and using coupons. Shopping tendency factors were found as pursuit of pleasure, pursuit of sociality, and pursuit of economic feasibility. Consumption behavior factors were categorized into impulsive buying, ostentatious consumption, utilization of internet information, possession of material and brand trust. Price-attitude toward apparel products had a significant effect on shopping values and consumption behavior. University students seemed to consider the value of money to be very important as well as economic feasibility. They utilized information from the internet to buy products with good quality and showed high usage level of coupons. And, university students who buy at a least price tried to show dignity with expensive brand products and they consider those brands express self-confidence.
\end{abstract}

Key Words : Price Attitude toward Apparel Products, Shopping Values, Consumption Behavior

\section{Introduction}

Recently overall economic environment is shrinking with job-insecurity and with an rapid increase in price in domestic and foreign markets.
Accordingly consumers tend to purchase smartly by opening the wallet on products worth buying and they buy products weighing up practicality, value and economic feasibility as well as price

Corresponding author: Park Eunhee, Tel. +82-53-950-6220, Fax.+82-53-950-6219

E-mail: parkh1987@hanmail.net 
and design. ${ }^{1)}$ Especially, their consuming behavior appears to purchase what they like and want to have regardless of price and at the same time they tend to show ambivalent consumption behavior by clinging to small discount such as coupons or milage. ${ }^{2)}$ The price related to these apparel products can be a standard for an objective judgement so that consumers can use this information without fail. As clothes are high value products, the price range is wide and has a frequent fluctuation. In this way, apparel products exist in various prices and on their characteristics, the purchase is related to symbolic and emotional attributes as well as practical attribute, therefore the influence of price on purchase process is many-sided. ${ }^{3)}$ Accordingly apparel products have a great risk in consuming process as they have a big gap between price and quality and it's difficult to judge on intrinsic attributes. The price can be an important cue for decision making as it substitute that, which raises a need to grasp the consumption behavior related to the price which plays an important role as an important cue for a decision of purchasing products.

Consumers perceive coincidently practical values and the pleasure of shopping experience itself. And as modern consumers have an increased interest in clothes or fashion, they enjoy shopping motivated by a motive of spending their leisure time to understand fashion trends or to get some pleasure by looking around some events or displays in addition to a simple purchase motive. ${ }^{4)}$ Equally, consumers want to get social shopping values where they can get some pleasure by forming human relationship from getting information in meeting people around or sales people in a shopping situation. That is, consumers put values on communication by salespeople and others and getting information in shopping spaces. In this study, shopping values refer to continuous beliefs or values which consumers have on situation or behavior of shopping. Consumers can get planned goals in purchasing products from a practical shopping and they also can get values from pleasurable shopping such as pleasure. As values can come from social shopping by human relationship, this study tried to examine the shopping values in a broad sense.

Attitude forms a preference toward products and the preference is connected to buying intention of consumers and again inducts buying behavior. Price is used as the most representative index because consumers are mostly using price and quality as an index of product evaluation and the price is specific and measurable. The price of apparel products as fashion products differentiate the values by the time and proper price strategy can create benefits but the price strategy behind time requires decrease in price, which can be a big loss. ${ }^{5)}$ Accordingly marketers of a fashion company need to increase buying behavior of consumers by understanding what the core values that make consumers buy products of the company and the judgement standards on the result of acquiring products in shopping situation would be by the price level.

Previous studies related to price in clothing mainly deal with price dimensions and buying behavior, ${ }^{6778) 9910)}$ objective purpose of usage and social situation according to being with or without company ${ }^{11)}$ and the vanity ${ }^{12)}$ which is a psychological attribute.

As apparel products are purchased and consumed psychologically rather than reasonably, the price perceived by consumers might have different meaning by the consumers 
Park Eunhee - Lee Sangjoo / Effects of Price Attitude toward Apparel Products on Shopping Values and Consumption Behavior

even with the same price and this meaning can be different by the psychological attributes. ${ }^{13)}$ That's why this study focuses on shopping values which is the psychological attribute and examine the price attitude and shopping values actually pursued by consumers. This study is to find out the effect of price-attitude toward apparel products on shopping values and consumption behavior.

\section{Background}

\section{Price-attitude toward apparel products}

Price is an expense to pay which can be a negative cue for giving up or delaying buying and at the same time it can be a positive cue for promoting buying. That is, price is perceived as the cash to be paid for buying. High price can be a negative cue that prohibits from buying while it can be a positive cue when consumers think higher priced products have better quality or it can be ostentatious. Generally consumers use price as an easy method for evaluation of quality and most of consumers think high priced products to be good products with quality but the buying intention can be lowered with the excessively high price. The reason why consumers purchase through promotion price such as a discount is the pleasure from the process of using these promotion activities rather than they can buy products in cheaper price. That is, perception of comparative saving thinking that they can buy cheaper than others do, than other times and than other places not that they compare the price or other attributes of apparel products can have positive effect on buying. ${ }^{14)}$

Looking into terms related to price, perceived price refers to a subjective perception of consumers on the price of goods or service, which differs by an individual. Price importance refers to the will to pay the money according to the level of individual perception and more important, more chances to pay. Price acceptability refers to the degree of judgement on the acceptable price range saved in an individual's memory. ${ }^{15)}$ Accordingly, price attitude toward apparel products in this study is an individual's subjective value, which refers to the expense paid through emotional and perceptional evaluation in buying process.

Lee Kyuhye and Rhee Eunyoung put price-dignity association, discount orientation and price leading into behavior related to the price of apparel products as well as low price orientation, utility value orientation and price-quality association and suggested these three kinds of behavior to be a special one related to the price of apparel products. ${ }^{16)}$ Park Sangmi and Lee Eunhee also suggested that the price that consumers perceive is multi-dimensional and it makes various reaction of price orientation accordingly. The price of apparel products were divided into the dimensions as high price orientation, discount orientation, high price quality orientation, low price orientation and utility orientation and they suggested the reason why the price professionality in Jin Byoungho's study ${ }^{17)}$ and the concept of price leading in Lee Kyuhye and Rhee Eunyoung's study ${ }^{18)}$ were not assorted into one factor is that the prices given by marketers are too various as the price competition gets higher. ${ }^{19)}$ In Jin Byoungho's sutdy, consumers with high interest and clothes importance perceive that high price of apparel products leads to the perception of good quality and they think high priced clothes represent the social positions, tell others about the price information 
and pursue the best quality against the money paid. Consumers with high fashion involvement think high priced clothes have good quality and they have low frequency of buying clothes on sale. ${ }^{20)}$ Nam Eunha and Lee Jinhwa suggested when consumers have practical tendency in choosing what to buy they can be so sensitive to the price of fashion products if they're alone while consumers with hedonic shopping value tendency in choosing products for present, they can be less sensitive to the price of the product even in case of buying he same products if they are accompanied by others. ${ }^{21)}$ As above, purchase decision making can be different according to the level of price perception because consumers have different evaluation on products of same price by personal standards of their own. ${ }^{22)}$ This study tried to examine the price attitude in regard of judgement and standards in paying money when they make purchase decisions of apparel products they usually wear.

\section{Shopping values}

Values refer to the standard for judgement when deciding things in daily life and the expressed behaviors can be different by the values. Shopping values accordingly make consumers behave different by their own judgement standards in shopping situation. That is, consumers perceive the practical values and at the same time they perceive the pleasure in shopping experience itself when they acquire products. In this way, hedonic shopping values and practical shopping values are widely used in consumer behavior studies. Hedonic shopping values refer to the level of perception that emotional benefits and shopping are valuable as well as visible results got from acquiring products. In this hedonic shopping value, poly-sensors, illusional image and emotional disenchantment are important factors. ${ }^{23)}$ In practical shopping values, consumers purchase products on the basis of reasonable judgement appeared in making a rational judgement collecting the information about needed products. This can be appeared when consumers tend to think shopping to be the work for acquiring something related to tasks. And consumers value getting information from and communication with salespeople or others in stores. Therefore, this study tried to examine shopping values relating practical shopping values, hedonic shopping values and social shopping values.

Kwon Dohee suggested that consumers with practical shopping values sensitive to fashion brands considers fashion brands as an important tool for product information to reduce uncertainty and to make a reasonable judgement. And Kwon Dohee also suggested consumers who have practical values and low sensitivity to fashion brands would be more sensitive to the part related to the practicality of fashion products such as price or quality. ${ }^{24)}$ Park Hyunhee, Ku Yangsuk and Koo Dongmo suggested there is no statistically significant difference by the price level in between hedonic shopping values and esthetic attributes of apparel products and in between practical shopping values and physical attributes of apparel products from the study of moderating effect of price level in between shopping values and attributes of apparel products. ${ }^{25)}$ Nam Eunha and Lee Jinhwa's study showed that the consumers with practical shopping value tendency were less sensitive to price than those with hedonic shopping value tendency, which means that even in case of purchasing the same product, the group with practical shopping 
Park Eunhee - Lee Sangjoo / Effects of Price Attitude toward Apparel Products on Shopping Values and Consumption Behavior

value tendency has willingness to try to pay less than the group with hedonic shopping value tendency does. And consumers who purchase fashion products for self-usage are less sensitive than those who purchase products for presents. $^{26)}$

Accordingly, this study tried to examine the shopping values and price attitude on the basis of the standards used to make an action in consumers' shopping situation.

\section{Consumption Behavior}

Current university students are the generation grown up with affluent material support and they have faced western individualism and pluralism and at the same time they play a leading role in information as their utilization level of information is high. They invest freely on what they feel to be valuable to express their image and personal characteristics as a subject of consumption and they show reasonable and sytematic consumption behavior to satisfy their various needs. ${ }^{27)}$ Accordingly, this study tried to examine consumption behavior dividing into impulsive buying, ostentatious consumption, utilization of internet information, possession of material, and brand trust.

Consumption behavior refers to mental and physical behavior process appeared in decision making process accompanying in acquiring, using, and disposing of goods and service to satisfy the needs. ${ }^{28)}$ Impulsive buying refers to the behavior of instantly reacting without careful consideration at a given stimulation and of buying a product on the spot without searching information after exposure to the product not intended to buy. Ostentatious consumption refers to the behavior of buying and using goods or service with which consumers can flaunt their wealth to others on purpose of acquiring or maintaining a position or to be upwardly mobile. ${ }^{29)}$ The frugal buying pattern of university students is expanding and the students are utilizing the information on the internet. That is, the usage level of internet is high as internet gives another chances such as easy comparison, quick handling of delivery and comfortable usage with price competence. Materialism is just like personality characteristics of an individual assorting people who put importance on their possessions in their life and those who do not. ${ }^{30)}$ Brand awareness refers to the ability to recognize or memorize a specific brand of a product bandwidth, and this helps form an image and an attitude toward a brand. $^{31)}$

Lee Heeseung and Lim Sookja suggested that in evaluation of blue jeans, university students evaluate them by the price they orient not by the popularity of the brand in case of pursuing high price or low price. On the other hand, university students who pursue popular brands or nameless brands have quality evaluation and buying intention influenced not by the price level but by the brands of their orientation. This study also suggested that giving prominence to perceived value for consumers would be better to attract buying than making perceived quality high. $^{32)}$ Lee Kyuhye and Rhee Eunyoung disclosed the fact that consumers behavior related to perception of apparel product price is many-sided and its effect on buying attitude or behavior on apparel products is also various. Price leading refers to the behavior of consumers who have a big knowledge on price information to become a source of market price information by delivering the information to others through communication. In actual purchasing, they turned out not to be low-price orientated, which is related to considering the 
price in communication step before purchase. ${ }^{33)}$ Park Sangmi and Lee Eunhee suggested that the utility orientation appeared to be highest among factor loading of price orientation for apparel products of university student consumers, which means they pursue the value of a product more than the money to be paid as they don't try to find high-priced products, rather they try to find a product with better quality at a lower price. The result also showed that the tendency of popular brand ostentation, fashion pursuing ostentation and position symbol ostentation appeared higher in female students. ${ }^{34)}$ Park Hyejung and Jeon Kyungsook explained that pursuit of success among materialism factors has only one significant path in normative agreement, which means success-oriented materialism tendency causes a normative agreement that adapts and accepts the social norms and found a significant effect of pursuit of happiness only on clothing importance in fashion tendency. ${ }^{35)}$ Song Jungmin suggested the more recognition of Marc Jacobs and MiuMiu as luxury items, the higher recognition of brand and excellence of quality and values. The study also suggested the higher recognition of masstige brands, the better brand attitude and brand image. ${ }^{36)}$ As above, university students showed consuming behavior related to impulsive buying, ostentatious consumption, utilizing internet information, material possession, and brand recognition in the process accompanied by acquiring and using goods and service for satisfying needs and wants as subjects of consumption. This study tried to examine the price attitude related to consuming behavior.

\section{Methods}

\section{Research problems}

1. This study is to understand the factor structure such as price-attitude of apparel products, shopping values, consumption behavior and so on.

2. This study is to find out the effect of price-attitude toward apparel products on shopping values and consumption behavior.

3. This study is to examine the difference of price-attitude toward apparel products on shopping values and consumption behavior in university students by gender.

\section{Data collection and analysis}

Before the main survey, a pilot test was carried out through July, 2012 intended for university students in Daegu and Kyoungbuk area, and the result offered a basic ground for main survey. The main survey was carried out from Sep. 03, 2012 to Sep. 13, 2012 intended for 350 university students living in Daegu and Kyoungbuk area. Total 326 surveys excluding insincere ones were used for data analysis. Among those objects, male students were $121(37.1 \%)$ and female students were 205(62.9\%). Monthly household income showed various results as more than 1 mil and less than 2 mil(won) were 12(3.7\%), less than 3 mil. $86(26.4 \%)$, less than 4 mil. $93(28.5 \%)$, less than 5 mil. 56 (17.2\%) and more than 5 mil. were $79(24.2 \%)$ with the average more than 2 mil. and less than $4 \mathrm{mil}$ (54.9\%).

SPSS PC+ 18.0 statistics program was used for data analysis with frequency and factor analysis, reliability analysis, regression analysis and t-test. 
Park Eunhee - Lee Sangjoo / Effects of Price Attitude toward Apparel Products on Shopping Values and Consumption Behavior

\section{Measures and process}

The measuring items extracted from previous studies such as price-attitude toward apparel products, shopping values and consumption behavior were modified and supplemented by the authors for this study. The validity for the measuring items was examined through pilot tests and each concept item was measured by 5 point Lickert scales(1: Strongly agree / 5: Strongly disagree). To gather the data for price-attitude toward apparel products, shopping values and consumption behavior survey method was used. And this study selected clothes which university students usually wear as apparel product.

Price attitude toward apparel products is an individual's subjective value, which refers to the expense paid through emotional and perceptional evaluation in buying process. 25 questions modified and supplemented by the authors on the basis of existing studies ${ }^{37)}$ were asked by 5-point Lickert measure and higher the points, more positive price attitude.

Shopping values refer to the continuous beliefs or values that consumers have on situations or behavior of shopping, and 15 questions modified and supplemented by the authors on the basis of existing studies ${ }^{38)}$ were asked by 5 -point Lickert measure and higher the points, more positive shopping values.

Consumption behavior refers to a choice behavior appeared in the purchase decision making process accompanied by acquiring, using, disposing of goods and services for satisfying needs. Based on previous studies ${ }^{39}$ ) the 14 items modified and supplemented by the authors were used for measurement by 5 point Lickert scales and the more points, the more positive. Demographic variables were gender and household's monthly income with simple choice method.

\section{Results and Discussion}

\section{The factor structure of price-attitude toward apparel products, shopping values and consumption behavior}

1) The factor structure of price-attitude toward apparel products

6 factors were extracted as a result of factor analysis using Varimax rotation to examine the price-attitude toward apparel products of university students. Even an opposite meaning was included in questions and factor analysis was done with numerical value. Factor 1 is about telling which place might be better to buy apparel products better than others do, which was named as 'information leading'. Factor 2 is named as 'price dignity' for it's about thinking that buying high priced brands means dignity and it can show something to others. Factor 3 explains the behavior that tries to buy and mainly purchase brands on sale, which was named as 'price discount'. Factor 4 explains the behavior of not trying to find a cheaper place and thinking this kind of behavior to be useless, which was named price professionality. Factor 5 refers to the behavior of trying to purchase clothes with quality that compensates the money paid and of being interested in quality as well as price, which was named 'Quality value'. Factor 6 was named as 'Using coupons' as it describes the behavior of using coupons due to economic reasons. The result of credibility test by the factors showed .91 for factor 1 , .87 for factor $2, .84$ for factor $3, .80$ for factor $4, .82$ for factor 5, and .81 for factor 6 in Cronbach' $\alpha$ with total explanation of $69.34 \%$. The average 
<Table 1> Price-attitude toward apparel product

\begin{tabular}{|c|c|c|c|c|c|}
\hline Factor & Variables & Loading & $\begin{array}{l}\text { Eigen } \\
\text { value }\end{array}$ & $\begin{array}{c}\text { Accumulati } \\
\text { on variance } \\
(\%)\end{array}$ & $\begin{array}{c}\text { Cronbach's } \alpha \\
\text { (Mean) }\end{array}$ \\
\hline $\begin{array}{c}\text { Information } \\
\text { leading }\end{array}$ & $\begin{array}{l}\text { In regard to apparel products, I can tell better } \\
\text { which place might be good to buy than others. } \\
\text { Friends think of me to be a wonderful } \\
\text { information sharer about the price of clothes. } \\
\text { I like telling others about the price information of } \\
\text { apparel products. } \\
\text { I l like telling others how much to pay by the } \\
\text { kinds of clothes. } \\
\text { People ask the information about the price of } \\
\text { apparel products to me. }\end{array}$ & $\begin{array}{l}.86 \\
.82 \\
.80\end{array}$ & 3.80 & 15.21 & $\begin{array}{c}.91 \\
(2.70)\end{array}$ \\
\hline $\begin{array}{l}\text { Price } \\
\text { dignity }\end{array}$ & $\begin{array}{l}\text { Buying high-priced brand represents the dignity. } \\
\text { Buying high-priced products can tell something } \\
\text { to others. } \\
\text { Buying the most expensive brands makes me } \\
\text { feel like a noble. } \\
\text { I think others judge me by the brands I bought. } \\
\text { I have bought the most expensive brands as } \\
\text { others are watching me. } \\
\text { If I keep on buying low-priced products, friends } \\
\text { will think of me to be a cheap. }\end{array}$ & $\begin{array}{l}.84 \\
.79 \\
.80 \\
.74 \\
.71 \\
.61 \\
.66\end{array}$ & 3.64 & 29.77 & $\begin{array}{c}.87 \\
(2.35)\end{array}$ \\
\hline $\begin{array}{c}\text { Price } \\
\text { discount }\end{array}$ & $\begin{array}{l}\mid \text { try to buy brands on sale. } \\
\text { I buy the brands on sale mainly. } \\
\text { I have my favorite brands, but I bought them } \\
\text { mostly when they are on sale. } \\
\text { Being on sale of apparel products is the reason } \\
\text { why I buy clothes. } \\
\text { I think buying branded products on sale to be a } \\
\text { good choice. }\end{array}$ & $\begin{array}{l}.85 \\
.83 \\
.73 \\
.71 \\
.66\end{array}$ & 3.23 & 42.69 & $\begin{array}{c}.84 \\
(3.19)\end{array}$ \\
\hline $\begin{array}{c}\text { Price } \\
\text { profession } \\
\text { ality }\end{array}$ & $\begin{array}{l}\text { I don't walk around to find a cheaper one. } \\
\text { There's no use spending time to find a cheaper } \\
\text { price. } \\
\text { I don't put my efforts on finding cheaper price. } \\
\text { I mostly walk around several stores to find } \\
\text { cheaper price. }\end{array}$ & $\begin{array}{l}.85 \\
.84 \\
.76 \\
.64\end{array}$ & 2.56 & 52.94 & $\begin{array}{l}.80 \\
(2.44)\end{array}$ \\
\hline $\begin{array}{l}\text { Quality- } \\
\text { value }\end{array}$ & $\begin{array}{l}\text { try to buy clothes with quality equal to the } \\
\text { money paid. } \\
\text { My interest lies non only in low price but also } \\
\text { the quality of products. } \\
\text { I check up the values enough to pay money } \\
\text { when I buy clothes. }\end{array}$ & $\begin{array}{l}.88 \\
.78 \\
.82\end{array}$ & 2.41 & 62.57 & $\begin{array}{c}.82 \\
(4.02)\end{array}$ \\
\hline $\begin{array}{l}\text { Using } \\
\text { coupons }\end{array}$ & $\begin{array}{l}\text { I think it would be economic to use coupons. } \\
\text { It makes me feel better to be compensated by } \\
\text { coupon discount. }\end{array}$ & $\begin{array}{l}.82 \\
.81\end{array}$ & 1.69 & 69.34 & $\begin{array}{c}.81 \\
(3.75)\end{array}$ \\
\hline
\end{tabular}


Park Eunhee - Lee Sangjoo / Effects of Price Attitude toward Apparel Products on Shopping Values and Consumption Behavior

appeared high in quality-value orientation and using coupon, which means university students tend to considered quality as important as money paid and the rate of using coupons was high. This supports the result of Park Sangmi and Lee Eunhee's study which suggested university students pursue the values of products rather than the money as they persue better quality with lower price rather than high-priced products. $^{40)}$

2) The factor structure of shopping values

As a result of factor analysis with principal component analysis and Varimax rotation to understand the shopping values of university students,
3 factors were extracted. Factor 1 was named as 'pursuit of pleasure' for it described the behavior of loving to look around a shopping center even without purchasing apparel products. Factor 2 refers to the behavior of loving to chat with salespersons with the chance of getting advices or information about products, which was named as 'pursuit of sociality'. Factor 3 is about the behavior of planning ahead what to buy and purchase the product which was seen several times with consideration, and was named as 'pursuit of economic feasibility'. The factors' credibility test showed .90 for factor 1, .83 for factor 2, and .66 for factor 3 in Cronbach' $\alpha$ with total explanation of $61.78 \%$.

$<$ Table 2> Shopping values

\begin{tabular}{|c|c|c|c|c|c|}
\hline Factor & Variables & Loading & $\begin{array}{l}\text { Eigen } \\
\text { value }\end{array}$ & $\begin{array}{l}\text { Accumulation } \\
\text { variance } \\
(\%)\end{array}$ & $\begin{array}{c}\text { Cronbach's } \alpha \\
\text { (Mean) }\end{array}$ \\
\hline $\begin{array}{l}\text { Pursuit of } \\
\text { pleasure }\end{array}$ & $\begin{array}{l}\text { I like to browse a shopping center. } \\
\text { Even though I don't buy fashion products, } \\
\text { I like to look inside for products. } \\
\text { I feel good to look around new-released } \\
\text { fashion products. } \\
\text { Shopping is good for refreshment. } \\
\text { When I am blue, shopping makes me feel } \\
\text { better. } \\
\text { I tend to purchase a unique or a } \\
\text { new-released fashion product at sight. }\end{array}$ & $\begin{array}{l}.85 \\
.84 \\
.82 \\
.81 \\
.79 \\
.60\end{array}$ & 4.11 & 27.39 & $\begin{array}{c}.90 \\
(3.45)\end{array}$ \\
\hline $\begin{array}{l}\text { Pursuit of } \\
\text { sociality }\end{array}$ & $\begin{array}{l}\text { I enjoy talking with salespeople in stores } \\
\text { as they understand what I want. } \\
\text { I enjoy shopping as I can get some } \\
\text { advice or information on products. } \\
\text { I enjoy shopping as I can meet people. } \\
\text { I enjoy shopping to refresh myself and to } \\
\text { see people. } \\
\text { I shop to convince the product I bought } \\
\text { to be the best quality at the price level. }\end{array}$ & $\begin{array}{l}.82 \\
.80 \\
.74 \\
.69 \\
.66\end{array}$ & 3.02 & 47.52 & $\begin{array}{c}.83 \\
(2.80)\end{array}$ \\
\hline $\begin{array}{l}\text { Pursuit of } \\
\text { economic } \\
\text { feasibility }\end{array}$ & $\begin{array}{l}\text { I think of what to buy in advance. } \\
\text { I budget in advance to buy fashion } \\
\text { products. } \\
\text { I buy a fashion product after thinking over } \\
\text { several times about the fashion product } \\
\text { which I made a usual plan to buy. } \\
\text { It is needed to invest time not to buy } \\
\text { products with bad quality when shopping. }\end{array}$ & $\begin{array}{l}.78 \\
.76 \\
.69 \\
.61\end{array}$ & 2.14 & 61.78 & $\begin{array}{l}.66 \\
(3.70)\end{array}$ \\
\hline
\end{tabular}


The average showed high in pursuit of economic feasibility, which means university students enjoy economic shopping by checking the product twice if it is needed, planning the budget and purchasing after that.

3) The factor structure of consumption behavior

As a result of factor analysis with principal component analysis and Varimax rotation to understand the consumption behavior of university students, 5 factors were extracted. Factor 1 was named as 'impulsive buying' for it explains the behavior of purchasing first, thinking later and not delaying in buying what they like. Factor 2 refers to the behavior of 'ostentatious consumption' with belief that having a specific brand represents my social position and it helps self-confidence. Factor 3 is about the behavior that finds information from the internet and visiting the shopping mall sites for purchase and was named 'utilization of internet information'. Factor 4's behavior put emphasis on the fact that economic power matters living in the world and material abundance is very important for happy life, and this factor was named as 'material possession'. Factor 5 is about the behavior of tending to trust the quality of products sold in famous department stores, which

$<$ Table $3>$ Consumption behavior

\begin{tabular}{|c|c|c|c|c|c|}
\hline Factor & Variables & Loading & $\begin{array}{l}\text { Eigen } \\
\text { value }\end{array}$ & $\begin{array}{c}\text { Accumulation } \\
\text { variance } \\
(\%)\end{array}$ & $\begin{array}{c}\text { Cronbach's } \alpha \\
\text { (Mean) }\end{array}$ \\
\hline $\begin{array}{l}\text { Impulsive } \\
\text { buying }\end{array}$ & $\begin{array}{l}\text { I buy first what I want to without } \\
\text { thinking. } \\
\text { I buy frist what fits me without } \\
\text { delaying. } \\
\text { I sometimes purchase on my } \\
\text { temporary mood. } \\
\text { At a store, I sometimes buy a product } \\
\text { which was not planned. }\end{array}$ & $\begin{array}{l}.85 \\
.83 \\
.81 \\
.61\end{array}$ & 2.49 & 17.79 & $\begin{array}{l}.79 \\
(3.09)\end{array}$ \\
\hline $\begin{array}{l}\text { Ostentatious } \\
\text { buying }\end{array}$ & $\begin{array}{l}\text { It's important to me if a product can } \\
\text { represent my social position. } \\
\text { Possession of a specific brand is } \\
\text { helpful for self-confidence. } \\
\text { t tend to buy products with } \\
\text { well-known brands. } \\
\text { I buy products with popular brands } \\
\text { even though they are expensive. }\end{array}$ & $\begin{array}{l}.81 \\
.74 \\
.72 \\
.64\end{array}$ & 2.23 & 33.71 & $\begin{array}{l}.75 \\
(2.96)\end{array}$ \\
\hline $\begin{array}{l}\text { Utilization of } \\
\text { internet } \\
\text { information }\end{array}$ & $\begin{array}{l}\text { I visit several internet shopping site } \\
\text { for buying products. } \\
\text { get information by visiting } \\
\text { ginformation providing sites on the } \\
\text { internet. }\end{array}$ & $\begin{array}{l}.89 \\
.86\end{array}$ & 1.59 & 45.06 & $\begin{array}{l}.72 \\
(3.64)\end{array}$ \\
\hline $\begin{array}{c}\text { Material } \\
\text { possession }\end{array}$ & $\begin{array}{l}\text { Economic power is most important to } \\
\text { live in the world. } \\
\text { Material affluence is very important } \\
\text { above all for a happy life. }\end{array}$ & $\begin{array}{l}.85 \\
.84\end{array}$ & 1.56 & 56.23 & $\begin{array}{l}.69 \\
(3.65)\end{array}$ \\
\hline Brand trust & $\begin{array}{l}\text { Quality can be trustable if bought in } \\
\text { well-known department stores. } \\
\text { I can have more trust on well-known } \\
\text { products. }\end{array}$ & $\begin{array}{l}.82 \\
.81\end{array}$ & 1.55 & 67.28 & $\begin{array}{l}.64 \\
(3.31)\end{array}$ \\
\hline
\end{tabular}


Park Eunhee - Lee Sangjoo / Effects of Price Attitude toward Apparel Products on Shopping Values and Consumption Behavior

was named 'brand trust'. The factors' credibility test showed .79 for factor 1, .75 for factor 2 , and .72 for factor 3, .69 for factor 4 and .64 for factor 5 in Cronbach' $\alpha$ with total explanation of $67.28 \%$.

The average showed high in utilization of internet information, which means university students think economic feasibility to be important and they get information from the internet. This supports the study of Park Sangmi and Lee Eunhee's as it showed not high points in ostentatious consumption. ${ }^{41)}$

\section{The effect of price-attitude toward apparel products on shopping values and consumption behavior}

Regression analysis was done to understand the effect of price-attitude toward apparel products on shopping values, and its result came out like the table 4 as follows. There is a significant effect of information leading, price discount, quality values and using coupons in price-attitude toward apparel products on pursuit of pleasure in shopping values with $25 \%$ of explanation. The students can tell friends about better places to buy, they use coupons and purchase mainly brands on sale. They also try to buy clothes with quality as much as the money they paid, enjoy window-shopping and they feel better after shopping. Information leading, price dignity, price discount and quality values in price-attitude toward apparel products appeared to have a significant effect on pursuit of sociality in shopping values with 19\% of explanation. They love to share price-information of apparel products and they also purchase products on sale but they believe the money represents the dignity and they want to have some conviction by shopping. Price-discount orientation, list price orientation, quality value orientation and using coupons in price-attitude turned out to be significantly effective on pursuit of economic feasibility in shopping values with $33 \%$ of explanation which is the highest. University students who visit several stores to buy clothes with enough quality as the money paid, who think themselves to be wonderful information providers and purchase branded products on sale appeared to plan a budget before purchase and invest their time. This result supports Kown Dohee's study that suggested consumers with practical values and low fashion brand sensibility are more sensitive to the part related to practicality of fashion products such as price or quality besides fashion brands. ${ }^{42)}$ On the other hand, this result is different from that of Park Hyunhee, Ku Yangsuk and Koo Dongmo's study where no moderating effect was found in a connection linkage among hedonic shopping values, esthetic attributes of apparel products and practical shopping values and physical attributes of apparel product. ${ }^{43)}$ Even though list price orientation in price attitude toward apparel products had no effect on pursuit of pleasure in shopping behavior, it had a negative effect on pursuit of economic feasibility, which supports Nam Eunha and Lee Jinhwa's study which suggested that consumers with tendency of practical shopping values have more sensitivity to price than those with hedonic shopping values. ${ }^{44)}$

Regression analysis was done to understand the effect of price-attitude toward apparel products on consumption behavior, and its result came out like the table 5 as follows. Information leading and price dignity in price-attitude toward apparel products showed a significant effect on impulsive buying in consumption behavior with $7 \%$ of explanation. University students who love 
$<$ Table 4> The effect of price-attitude toward apparel products on shopping values

\begin{tabular}{|c|c|c|c|c|c|}
\hline $\begin{array}{l}\text { Dependent } \\
\text { variable }\end{array}$ & Independent variable & $\beta$ & $t$ & F & $R^{2}$ \\
\hline $\begin{array}{l}\text { Pursuit of } \\
\text { pleasure }\end{array}$ & $\begin{array}{l}\text { Information leading orientation } \\
\text { Price dignity orientation } \\
\text { Price discount orientation } \\
\text { Price professionality } \\
\text { Quality value orientation } \\
\text { Using coupons }\end{array}$ & $\begin{array}{l}.45 \\
.07 \\
.10 \\
.02 \\
.11 \\
.12\end{array}$ & $\begin{array}{l}9.38^{\star \star \star} \\
1.40 \\
2.05^{\star} \\
.35 \\
2.23^{\star} \\
2.40^{\star}\end{array}$ & $17.50^{\star \star \star}$ & .25 \\
\hline $\begin{array}{l}\text { Pursuit of } \\
\text { sociality }\end{array}$ & $\begin{array}{l}\text { Information leading orientation } \\
\text { Price dignity orientation } \\
\text { Price discount orientation } \\
\text { Price professionality } \\
\text { Quality value orientation } \\
\text { Using coupons }\end{array}$ & $\begin{array}{r}.28 \\
.20 \\
.16 \\
.10 \\
-.19 \\
-.07 \\
\end{array}$ & $\begin{array}{l}5.47^{\star \star \star} \\
3.98^{\star \star \star} \\
3.13^{\star \star} \\
1.88 \\
-3.75^{\star \star \star} \\
-1.35 \\
\end{array}$ & $12.49^{\star \star \star}$ & .19 \\
\hline $\begin{array}{l}\text { Pursuit of } \\
\text { economic } \\
\text { feasibility }\end{array}$ & $\begin{array}{l}\text { Information leading orientation } \\
\text { Price dignity orientation } \\
\text { Price discount orientation } \\
\text { Price professionality } \\
\text { Quality value orientation } \\
\text { Using coupons }\end{array}$ & $\begin{array}{l}.21 \\
-.07 \\
.16 \\
-.26 \\
.40 \\
.16 \\
\end{array}$ & $\begin{array}{l}4.51^{\star \star \star} \\
-1.55 \\
3.40^{\star \star \star} \\
-5.61^{\star \star \star} \\
8.69^{\star \star \star} \\
3.52^{\star \star \star}\end{array}$ & $25.61^{\star \star \star}$ & .33 \\
\hline
\end{tabular}

${ }^{*} \mathrm{p}<.05,{ }^{* *} \mathrm{p}<.01,{ }^{* * *} \mathrm{p}<.001$

to talk with friends about how much to pay by the apparel product items and who think friends would evaluate by the brands turned out to purchase right away the product which was planned to buy in a proper period of time even though they didn't intend to. And information leading, price dignity and list price orientation in price attitude toward apparel products has a significant effect on ostentation consumption in consumption behavior with $41 \%$ of explanation which was the highest. The university students who think purchasing expensive branded products represents their dignity, give lots of information about apparel products to friends and try to buy at a list price rather than at a discounted price appeared to have self-confidence by possessing apparel products with specific brands. This result supports the study of Jin Byoungho's which suggested the reason of paying expensive when buying apparel products is that those consumers believe expensive products can represent the dignity of those who wear. ${ }^{45)}$ Information leading, list price orientation, quality values and using coupons in price attitude toward apparel products turned out to have a significant effect on utilization of internet information in consumption behavior with $17 \%$ of explanation. The university students who are great information providers, check up if the product would have enough value as the money paid, try to purchase products with good quality and use coupons showed a tendency to get information from visiting various internet sites. This supports the result of Lee Kyuhye and Rhee Eunyoung's study which suggested that consumers whose behavior is to be the source of market price information delivering through communication are related to consider price in the phase of communication before purchase as they turned out not to be low price oriented. ${ }^{46)}$ 
Park Eunhee - Lee Sangjoo / Effects of Price Attitude toward Apparel Products on Shopping Values and Consumption Behavior

Price dignity and quality values in price attitude toward apparel products appeared to have a significant effect on material possession with $10 \%$ of explanation. The university students who have high intention of showing friends that expensive apparel products can show something and try to buy products worthwhile paying the money appeared to think economic power is most important above all. Price dignity appeared to have a significant effect on brand trust in consumption behavior with $3 \%$ of low explanation.
The university students who buy expensive clothes for their dignity turned out to believe the quality of products sold in well-known department stores.

\section{The difference in price-attitude toward apparel products, shopping values, and consumption behavior by gender}

The result of t-test to understand the difference in price-attitude toward apparel products,

$<$ Table $5>$ The effect of price-attitude toward apparel products on consumption behavior

\begin{tabular}{|c|c|c|c|c|c|}
\hline $\begin{array}{l}\text { Dependent } \\
\text { variable }\end{array}$ & Independent variable & $\beta$ & $t$ & $F$ & $R^{2}$ \\
\hline $\begin{array}{l}\text { Impulsive } \\
\text { Buying }\end{array}$ & $\begin{array}{l}\text { Information leading orientation } \\
\text { Price dignity orientation } \\
\text { Price discount orientation } \\
\text { Price professionality } \\
\text { Quality value orientation } \\
\text { Using coupons }\end{array}$ & $\begin{array}{l}.16 \\
.12 \\
.05 \\
.09 \\
-.10 \\
-.09\end{array}$ & $\begin{array}{l}2.92^{\star \star} \\
2.18^{\star} \\
1.00 \\
1.73 \\
-1.91 \\
-1.65\end{array}$ & $3.93^{\star \star \star}$ & .07 \\
\hline $\begin{array}{l}\text { Ostentatious } \\
\text { consumption }\end{array}$ & $\begin{array}{l}\text { Information leading orientation } \\
\text { Price dignity orientation } \\
\text { Price discount orientation } \\
\text { Price professionality } \\
\text { Quality value orientation } \\
\text { Using coupons }\end{array}$ & $\begin{array}{l}.25 \\
.58 \\
.06 \\
.11 \\
-.03 \\
.03\end{array}$ & $\begin{array}{c}5.83^{\star \star \star} \\
13.37^{\star \star \star} \\
1.38 \\
2.47^{\star} \\
-.78 \\
.68\end{array}$ & $36.97^{\star \star \star}$ & .41 \\
\hline $\begin{array}{c}\text { Internet } \\
\text { Information }\end{array}$ & $\begin{array}{l}\text { Information leading orientation } \\
\text { Price dignity orientation } \\
\text { Price discount orientation } \\
\text { Price professionality } \\
\text { Quality value orientation } \\
\text { Using coupons }\end{array}$ & $\begin{array}{l}.25 \\
-.04 \\
.06 \\
-.19 \\
.21 \\
.14\end{array}$ & $\begin{array}{c}4.86^{\star \star \star} \\
-.85 \\
1.09 \\
-3.75^{\star \star \star} \\
4.17^{\star \star \star} \\
2.72^{\star \star}\end{array}$ & $10.73^{\star \star \star}$ & .17 \\
\hline $\begin{array}{c}\text { Material } \\
\text { Possession }\end{array}$ & $\begin{array}{l}\text { Information leading orientation } \\
\text { Price dignity orientation } \\
\text { Price discount orientation } \\
\text { Price professionality } \\
\text { Quality value orientation } \\
\text { Using coupons }\end{array}$ & $\begin{array}{l}.05 \\
.23 \\
.01 \\
-.10 \\
.19 \\
.06\end{array}$ & $\begin{array}{l}.99 \\
4.25^{\star \star \star} \\
.09 \\
-1.91 \\
3.50^{\star \star \star} \\
1.13\end{array}$ & $6.04^{\star \star \star}$ & .10 \\
\hline $\begin{array}{l}\text { Brand } \\
\text { recognition }\end{array}$ & $\begin{array}{c}\text { Information leading orientation } \\
\text { Price dignity orientation } \\
\text { Price discount orientation } \\
\text { Price professionality } \\
\text { Quality value orientation } \\
\text { Using coupons } \\
\end{array}$ & $\begin{array}{l}-.03 \\
.12 \\
.05 \\
-.03 \\
.10 \\
.05 \\
\end{array}$ & $\begin{array}{c}-.53 \\
2.26^{\star} \\
.95 \\
-.52 \\
1.75 \\
.90 \\
\end{array}$ & 1.74 & .03 \\
\hline
\end{tabular}

${ }^{*} p<.05,{ }^{* *} p<.01,{ }^{* \star *} p<.001$ 
shopping values and consumption behavior by gender is like the table 6 below. There was significant differences with higher points of female students in information leading orientation of price-attitude toward apparel products, impulsive buying of consumption behavior, pursuit of pleasure of shopping values and utilization of internet information That is, female students are fond of talking about the information of apparel products to friends more than male students and they love to shop for refreshment and purchase first what they want to buy. On the other hand, there was no difference in price dignity of price-attitude, ostentatious consumption and brand trust of consumption behavior, which is different from the study of Park Sanhmi and Lee Eunhee's that suggested female students showed higher in high-price orientation, famous brand ostentation and representing positions. ${ }^{47)}$

\section{Conclusion}

This study examined the effect of price-attitude toward apparel products of university students on shopping values and consumption behavior and the results are as follows.

First, price-attitude toward apparel products of university students was categorized as information leading, price dignity, price discount, list price orientation, quality value and using coupons. Shopping tendency factors were pursuit of pleasure, pursuit of sociality, and pursuit of economic feasibility. Consumption behavior factors were impulsive buying, ostentatious consumption, utilization of internet information, possession of material and brand trust.

Second, price-attitude toward apparel products had a significant effect on shopping values and

$\langle$ Table 6> The difference in price-attitude toward apparel products, shopping values, and consumption behavior by gender

\begin{tabular}{|c|c|c|c|c|}
\hline \multirow{2}{*}{\multicolumn{2}{|c|}{ Variables }} & Male $(n=121)$ & Female $(n=205)$ & \multirow{2}{*}{ t-test } \\
\hline & & $\mathrm{M}(\mathrm{SD})$ & $\mathrm{M}(\mathrm{SD})$ & \\
\hline \multirow{6}{*}{$\begin{array}{c}\text { Price- } \\
\text { attitude } \\
\text { toward } \\
\text { apparel } \\
\text { products }\end{array}$} & Information leading orientation & $2.50(.87)$ & $2.82(.78)$ & $-3.435^{\star \star \star}$ \\
\hline & Price dignity orientation & $2.35(.79)$ & $2.36(.68)$ & -.09 \\
\hline & Price discount orientation & $3.10(.71)$ & $3.25(.73)$ & -1.73 \\
\hline & Price professionality & $2.46(.77)$ & $2.43(.71)$ & .33 \\
\hline & Quality value orientation & $3.95(.70)$ & 4.05(.63) & -1.30 \\
\hline & Using coupons & $3.66(.72)$ & $3.80(.73)$ & -1.61 \\
\hline \multirow{3}{*}{$\begin{array}{l}\text { Shopping } \\
\text { values }\end{array}$} & Pursuit of pleasure & $2.90(.80)$ & $3.69(.68)$ & $-9.10^{\star \star \star}$ \\
\hline & Pursuit of sociality & $2.70(.77)$ & $2.84(.70)$ & -1.57 \\
\hline & Pursuit of economic feasibility & $3.64(.60)$ & $3.72(.64)$ & -1.14 \\
\hline \multirow{5}{*}{$\begin{array}{c}\text { Consumption } \\
\text { behavior }\end{array}$} & Impulsive buying & $2.86(.79)$ & $3.22(.76)$ & $-4.01^{\star \star \star}$ \\
\hline & Ostentatious consumption & $2.93(.75)$ & $2.97(.68)$ & -.50 \\
\hline & Utilization of internet information & $3.48(.89)$ & $3.73(.82)$ & $-2.54^{\star *}$ \\
\hline & Material possessions & $3.62(.84)$ & $3.67(.76)$ & -.48 \\
\hline & Brand recognition & $3.23(.73)$ & $3.36(.72)$ & -1.59 \\
\hline
\end{tabular}

${ }^{* *} \mathrm{p}<.01,{ }^{* * *} \mathrm{p}<.001$ 
Park Eunhee - Lee Sangjoo / Effects of Price Attitude toward Apparel Products on Shopping Values and Consumption Behavior

consumption behavior and the results are as follows. The students can tell friends about better places to buy, they use coupons and purchase mainly brands on sale. They also tried to buy clothes with quality as much as the money they paid, enjoy window-shopping and they feel better after shopping. They loved to share price-information of apparel products and they also purchased products on sale but they believed the money represents the dignity and they wanted to have some conviction by shopping. University students who visited several stores to buy clothes of enough quality as much as they paid and those who think themselves to be wonderful information providers and purchase branded products on sale appeared to plan a budget before purchase and invest their time.

University students who love to talk with friends about how much to pay by the apparel product items and who think friends would evaluate by the brands turned out to purchase right away the product which was planned to buy in a proper period of time even though they didn't intend to. The university students who think purchasing expensive branded products represents their dignity, give lots of information about apparel products to friends and try to buy at a list price rather than at a discounted price appeared to have self-confidence by possessing apparel products with specific brands. The university students who are great information providers, check up if the product would have enough value as the money paid, try to purchase products with good quality and use coupons showed a tendency to get information from visiting various internet sites. Accordingly it can be understood that in making purchase decisions of apparel products price attitude, the price attitude appeared to be related to buying behavior in consumers' decision making process.
Third, female students are fond of talking about the information of apparel products to friends more than male students and they love to shop for refreshment and purchase first what they want to buy.

Accordingly, university students considers the value of money to be very important as well as economic feasibility. They utilized information from the internet to buy good-qualitied products and showed high usage level of coupons. On the other hand, university students who buy at a list price tried to show dignity with expensive brand products and they consider those brands express self-confidence. The result of factor analysis on price attitude showed its structure was multi-dimensional and university students had high interest in product quality considering using coupons would be economic. This study hereby included sociality-pursuit variables that explains the behavior of shopping influenced by sales people and other people around.

Based on these result, we can suggest several marketing strategy for companies dealing with university students. Stores should prepare to offer various kind of things to see for university students who love to visit stores. With easily visible POPs, the store can give information. Shops can make an integrated planning with various events and other places besides shopping spaces such as theater, exhibition place, restaurants, hair salon and etc. For the university students who have high intention of ostentation by giving friends information about what they have bought and by showing friends the best quality of what they have bought, stores can plan to give various benefits such as daily, weekly, and monthly events, differentiated discount rate, DM and etc, which will bring university student customers with their friends to show off. For the university students who 
purchase on the basis of planning money and time, stores can prepare customer cards for them and utilize the information on the card for 1 to 1 customized service for each customer.

This study used a sample which consisted of mainly university students who purchased apparel products, which calls for an necessity of expanded sample in size and types in future studies. And this study has a limitation of generalizing the results as the study used a convenience sampling method.

\section{Reference}

1) "Women's wear: Access with the keyword 'V-VIP'", (2012. 11. 01), Fashion channel, Retrieved 2012.11.10, from http://www. fashionchannel.co.kr

2) Nam Miwoo(2010), "Price attitude of apparel products and store choice behavior according to vanity type of college students", Journal of the Korean Home Economics Association, 48(2), pp.23-38.

3) Lee Kyuhye, Rhee Eunyoung(2002), "The multi-faceted influence of price on consumers' purchasing process of apparel products-Relationship with attitudinal and behavioral variables", Journal of the Korean Home Economics Association, 40(9), 1-15.

4) Hong Keumhee, Kang Hyelie(2003), "A study on the store choice criteria and store-related attitudes of consumers in accordance with the clothing shopping moitives and involvement of customers", Journal of Korean Society for Clothing Industry, 5(4), 363-371.

5) Lee Kyuhye, Rhee Eunyoung, op.cit., pp.1 -15 .

6) Jin Byoungho(1998), "Consumer's perception of clothing price(Part I )-Testing the validity of dimensions of clothing price", Journal of the Korean Society of Clothing and Textiles, 22(3), pp.417-427.

7) Jin Byoungho(1998), "Consumer's perception of clothing price(PartII)-The effect of product involvement and clothing price", Journal of the Korean Society of Clothing and Textiles, 22(5), pp.628-638.

8) Lee Heeseung, Lim Sookja(2000), "The effect of price and brand on the perceived quality, value and purchase of clothing", Journal of the Korean Society of Clothing and Textiles, 24(2), pp.498-509.

9) Lee Kyuhye, Rhee Eunyoung(2002), “Toward a conceptualization of clothing price perception: A taxonomy of shopping behavior", Journal of the Korean Society of Clothing and Textiles, 26(6), pp.877-888.

10) Park Sangmi, Lee Eunhee(2007), "The relation between the perception of price and the propensity to conspicuous-consumption in the purchase of clothing of college students", Korean Journal of Human Ecology, 16(2), pp.367-380.

11) Nam Eunha, Lee Jinhwa(2009), "Comparison of price sensitivity based on the shopping value, purpose of use and social situation", Journal of the Korean Society of Clothing and Textiles, 33(9), pp.1452-1462.

12) Nam Miwoo, op.cit., pp.23-38.

13) Ibid., pp.23-38.

14) Lee Kyuhye, Rhee Eunyoung, op.cit., pp.877 $-888$.

15) Suri R., Monroe, K. B.(2001), "The effects of need for cognition and trait anxiety on price acceptability. Psychology \& Marketing, 18(1), $21-42$.

16) Lee Kyuhye, Rhee Eunyoung, op.cit., pp.877 $-888$. 
Park Eunhee - Lee Sangjoo / Effects of Price Attitude toward Apparel Products on Shopping Values and Consumption Behavior

17) Jin Byoungho, op.cit., pp.417-427.

18) Lee Kyuhye, Rhee Eunyoung, op.cit., pp.877 $-888$.

19) Park Sangmi, Lee Eunhee, op.cit., pp.367 -380 .

20) Jin Byoungho, op.cit., pp.628-638.

21) Nam Eunha, Lee Jinhwa, op.cit., pp.1452 -1462 .

22) Kim Siwuel, Park Baejin(2003), "A study on the price sensitivity and postpurchase satisfaction in internet shopping mall", Journal of the Korean Home Economics Association, 41(9), pp.69-83.

23) Hirschman, E. C., Holbrook, M. B.(1982), "Hedonic consumption: Emerging concepts, methods and propositions. Journal of Marketing, 46(3), 92-101.

24) Kwon Dohee(2007), "The effects of consumer attitude based on shopping value, fashion brand sensitivity and types of collaboration", Sung Kwan University master's dissertation. pp.69-70.

25) Park Hyunhee, Ku Yangsuk, Koo Dongmo (2007), "The influence of consumer's shopping values on the evaluations of fashion product attributes and brand re-purchase intention-Focused on the moderating role of price level", Journal of the Korean Society of Clothing and Textiles, 31(2), pp.236-246.

26) Nam Eunha, Lee Jinhwa, op.cit., pp.1452 $-1462$.

27) Park Eunhee, Ku Yangsuk(2008), "Consumption value according to college students' self-efficacy typology", Korean Journal of Human Ecology, 17(5), pp.927-938.

28) Chun Moonsun, Lee Soogyung, Koh Aeran (2006), "The effect of cultural tendency on clothing consumption behavior", Korean Journal of Consumer and Advertising
Psychology, 7(2), pp.277-300.

29) Park Hyunju, Park Sookhyun(2012), "The effects of conspicuous consumption tendency on fashion involvement by age groups", Journal of Korean Society for Clothing Industry, 14(1), pp.56-63.

30) Park Hyejung, Jeon Kyungsook(2004), "Personal value determinants of fashion orientation: Materialism and consumer conformity", Journal of the Korean Society of Clothing and Textiles, 28(9/10), pp.1243-1252.

31) Song Jungmin(2007), "A study on the influence of consumer attitude towards extension of brand products-Focused on brand management of masstige", Journal of Korean Society of Communication Design, 10, pp.83-97.

32) Lee Heeseung, Lim Sookja, op.cit., pp.498 -509 .

33) Lee Kyuhye, Rhee Eunyoung, op.cit., pp.877-888.

34) Park Sangmi, Lee Eunhee, op.cit., pp.367 $-380$.

35) Park Hyejung, Jeon Kyungsook, op.cit., pp.1243-1252.

36) Song Jungmin, op.cit., pp.83-97.

37) Nam Miwoo, op.cit., pp.23-38.

38) Kwon Dohee(2007), op.cit., p.49.

39) Hong Sungtae, Kang Donggyun, Kim Mijun(2007), "Recognition Age: Analysis on consumption behavior and its intermediate effect. Journal of Consumer Studies, 18(3), pp.63-86.

40) Park Sangmi, Lee Eunhee, op.cit., pp.367 -380 .

41) Ibid., pp.367-380.

42) Kwon Dohee(2007), op.cit., p.70.

43) Park Hyunhee, Ku Yangsuk, Koo Dongmo, op.cit., pp.236-246. 
Journal of Fashion Business Vol.16, No.6

44) Nam Eunha, Lee Jinhwa, op.cit., pp.14521462.

45) Jin Byoungho, op.cit., pp.417-427.

46) Lee Kyuhye, Rhee Eunyoung op.cit., pp.1-1 5.

47) Park Sangmi, Lee Eunhee, op.cit., pp.367380.

접수일(2012년 11월 23일),

수정일(1차 : 2012년 12월 14일),

게재확정일(2012년 12월 21일) 